\title{
Novel tetrapodal molecules and reticular polyamides based on tetraphenylmethane
}

\author{
Journal Article \\ Author(s): \\ Lorenzi, Gian P.; Manessis, Andreas; Tirelli, Nicola C.; Gramlich, Volker \\ Publication date: \\ 1997 \\ Permanent link: \\ https://doi.org/10.3929/ethz-b-000423050 \\ Rights / license: \\ In Copyright - Non-Commercial Use Permitted \\ Originally published in: \\ Structural Chemistry 8(6), https://doi.org/10.1007/BF02311702
}




\title{
Novel Tetrapodal Molecules and Reticular Polyamides Based on Tetraphenylmethane
}

\author{
Gian P. Lorenzi, ${ }^{1,3}$ Andreas Manessis, ${ }^{1}$ Nicola C. Tirelli, ${ }^{1}$ and Volker Gramlich ${ }^{2}$
}

\begin{abstract}
Received March 4, 1997; revised May 26, 1997; accepted June 8, 1997
A series of tetrapodal derivatives of tetraphenylmethane were synthesized and characterized. Crystals obtained from tetrakis(4-acetamidophenyl)methane (1c) and from tetrakis[4-(4-aminobenzamido)phenyl]methane ( $2 \mathrm{~b}$ ) were analyzed by $\mathrm{X}$-ray diffraction. The analyses pointed to the crystal packing problems faced by molecules of this kind by showing that the crystals, with composition 1c $2 \mathrm{DMF} \cdot 2 \mathrm{H}_{2} \mathrm{O}$ and $2 \mathrm{~b} \cdot 2 \mathrm{DMSO}$, respectively, contained cocrystallized solvent molecules. The solvent molecules were found in both cases to be held in place by $\mathrm{H}$ bonds; in the case of 2b-2DMSO they occupied channels running along the $b$ axis. Tetrakis(4-aminophenyl)methane (1b) was used in polycondensation reactions with terephthalic acid, under modified Yamazaki conditions, to produce rigid aromatic polyamide networks. The networks were obtained as gels encompassing the whole volume of the reaction mixture. The volume of the gels did not vary noticeably upon changing the solvent (1-methyl-2-pyrrolidone) with less polar solvents, but the gels collapsed upon drying. No crystallinity was observed.
\end{abstract}

KEY WORDS: Tetraphenylmethane derivatives; tetrapodal molecule's crystal structure; rigid polyamides; porous networks.

\section{INTRODUCTION}

Tetrapodal [1] organic molecules exhibiting four identical stiff chains projecting from a common core toward the vertices of a tetrahedron have attracted recent attention as possible reinforcing agents $[1,2]$ in blends with other polymers, as monomers of four-armed star polymers $[3,4]$, and, in particular, as potential $[5,6]$ or actual [7-13] building blocks of three-dimensionally (3D) ordered, highly porous rigid networks. These networks, which can originate through self-assembling [713], or, in principle, through polymerization $[5-8,14$, 15], are interesting especially for possible applications in molecular separations and in catalysis. Work in all these fields, however, is only just beginning and the full

\footnotetext{
'Institut für Polymere, ETH-Zentrum, CH-8092 Zürich, Switzerland. ${ }^{2}$ Laboratorium für Kristallographie, ETH-Zentrum, CH-8092 Zürich, Switzerland.

${ }^{3}$ Correspondence should be directed to Gian P. Lorenzi, Institut für Polymere, ETH-Zentrum, CH-8092 Zürich, Switzerland.
}

potential of tetrapodal organic molecules is still to be assessed. These considerations and our interest in stiff aromatic polyamides [16] have led us to initiate a study of tetrapodal derivatives of tetraphenylmethane (1) of<smiles>CCc1ccc(CCNC(=O)c2ccc(CC)cc2)cc1</smiles>

formula and to try to use monomers of this kind to prepare rigid polyamide networks. In this paper we describe the syntheses of the derivatives with $n=0, \mathrm{R}=$ $\mathrm{NHCOCH}_{3}(1 \mathrm{c}), n=1, \mathrm{R}=\mathrm{NO}_{2}, \mathrm{NH}_{2}$, or $\mathrm{NHCOCH}_{3}$ (2a, $2 \mathrm{~b}$, and $2 \mathrm{c}$ ), and $n=2, \mathrm{R}=\mathrm{H}, \mathrm{NO}_{2}$, or $\mathrm{NH}_{2}(3$, 3a, and $\mathbf{3 b}$ ), present the crystal packing characteristics of crystals obtained from $1 c$ and $\mathbf{2 b}$, and report on some results of polycondensation reactions that we have carried out using $\mathbf{1 b}$ and terephthalic acid as monomers. Part of this work has already been communicated in preliminary form [17]. 


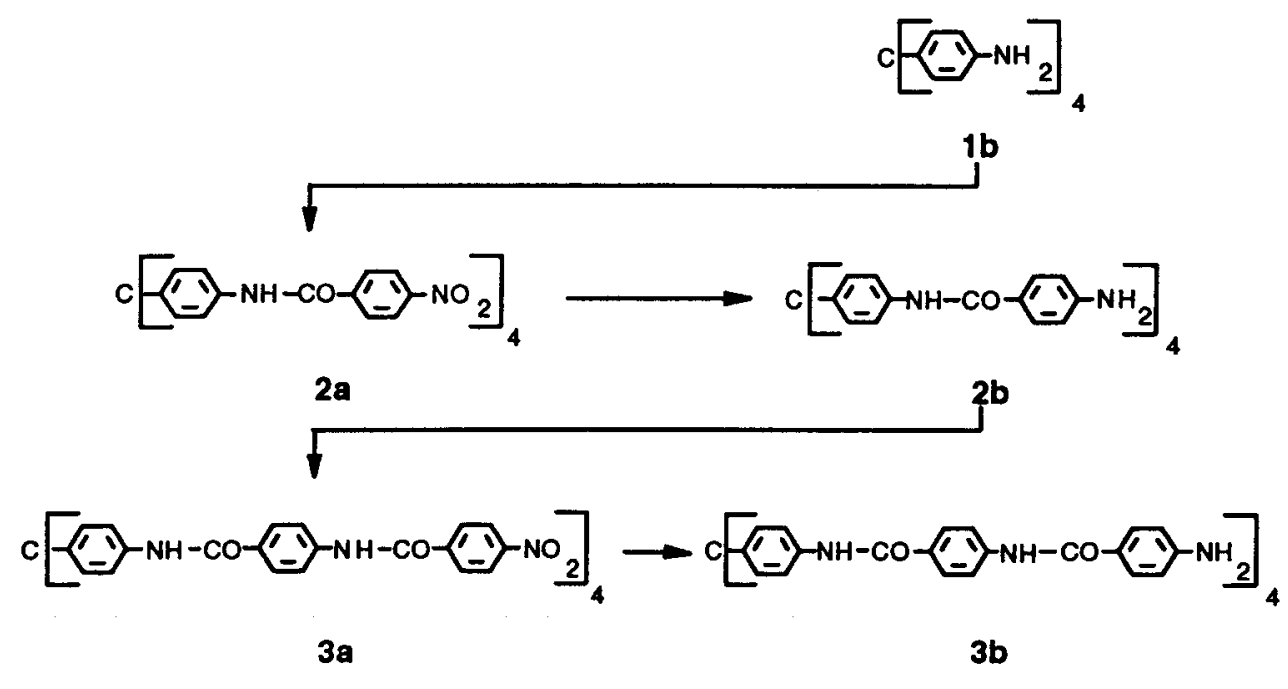

Scheme 1. Synthesis of the tetrapodal compounds.

\section{RESULTS AND DISCUSSION}

\section{Tetrapodal Compounds}

\section{Syntheses}

Tetrakis(4-aminophenyl)methane (1b) [18] was the starting material. Acylation with 4-nitrobenzoyl chloride and catalytic reduction-with hydrazine hydrate [19]-of the resulting tetranitro compound (2a) were used to obtain $\mathbf{2 b}$ and these two reactions were repeated to obtain $3 \mathbf{b}$ (Scheme 1). An obstacle to the extension of this simple procedure to the synthesis of even higher tetrapodal oligomers was posed by the rapid decrease in solubility accompanying the lengthening of the arms. $3 \mathrm{~b}$ was poorly soluble, and its solutions tended to gel upon standing. The ' $\mathrm{H}$ NMR spectra of this compound in DMSO- $d_{6}$ showed split signals of variable, concentration-dependent relative intensity, and revealed intermolecular NOE effects indicating aggregation. Interestingly, split ${ }^{1} \mathrm{H}$ NMR signals have been also observed by others for an aramid dendrimer of comparable size in the same solvent; the interpretation, however, has been different [20]. The exact nature of the aggregates formed by $\mathbf{3 b}$ was not investigated.

\section{Crystal Structures}

The tetrapodal structure and the potential for noncovalent interactions of the new molecules synthesized provided strong motivation for a study of their crystal packing behavior. Attempts to obtain crystals suitable for X-ray analysis were made with every product, but only in the cases of $1 \mathrm{c}$ and $\mathbf{2 b}$, using solutions in DMF/ nitrobenzene and DMSO/ $\mathrm{H}_{2} \mathrm{O}$, respectively, was it pos- sible to grow such crystals. The molecular conformations found for $\mathbf{1 c}$ and $\mathbf{2 b}$ are illustrated in Figs. 1 and 2 , respectively. The configuration of the central carbons is not exactly tetrahedral. In the case of 1c there are around the central carbons six different bond angles varying from $101.9^{\circ}$ to $115.0^{\circ}$; in the case of $2 \mathrm{~b}$, where the central carbons lie on a twofold crystallographic axis, there are around them four different bond angles and they range from $105.0^{\circ}$ to $112.0^{\circ}$. Similar distortions also have been observed with tetraphenylmethane [21] and with $\mathrm{Cu}^{\mathrm{I}}$ [tetrakis(4-cyanophenyl)methane] $\mathrm{BF}_{4} \cdot$ $x \mathrm{C}_{6} \mathrm{H}_{5} \mathrm{NO}_{2}$ [8]. All amide groups have the $\mathrm{Z}$-configuration. The arms of the central carbons of $1 c$-all conformationally different, albeit slightly-reach at the out-

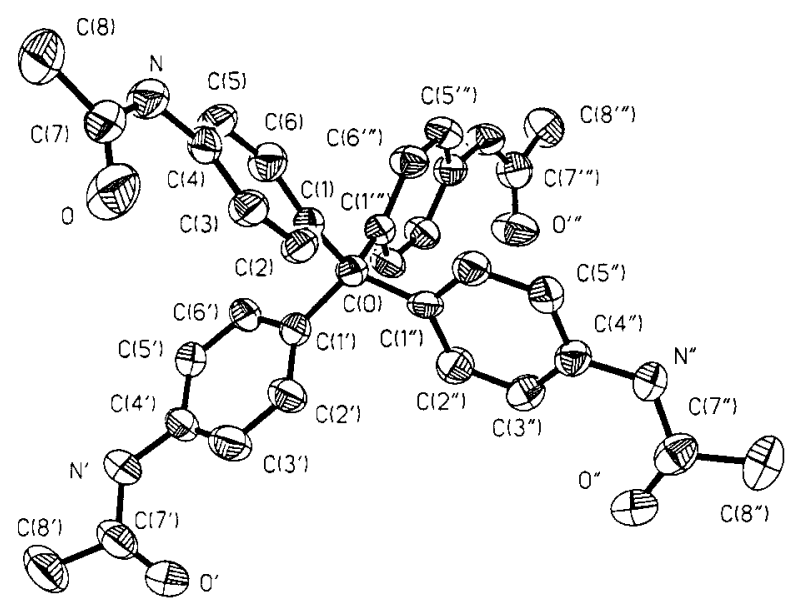

Fig. 1. ORTEP plot [22] (50\% probability ellipsoids) of 1c in crystals of $1 \mathrm{c} \cdot 2 \mathrm{DMF} \cdot 2 \mathrm{H}_{2} \mathrm{O}$, with the atom numbering. 


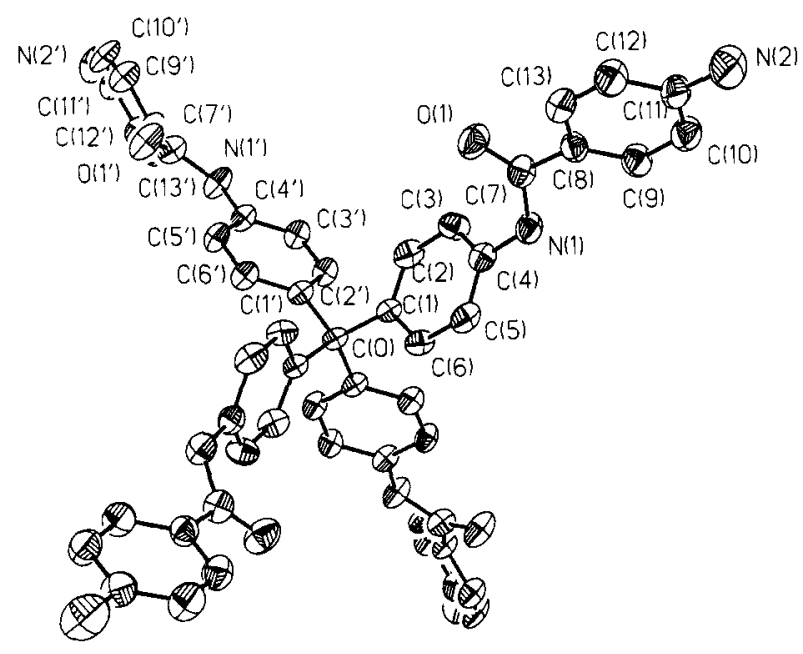

Fig. 2. ORTEP plot [22] (50\% probability ellipsoids) of $\mathbf{2 b}$ in crystals of $2 \mathbf{b} \cdot 2 \mathrm{DMSO}$, with the atom numbering.

ermost nonhydrogen atom a length of 8.08-8.12 $\AA$. Those of $2 \mathrm{~b}$-identical in pairs-measure 12.12 and $12.14 \AA$, respectively. Not surprisingly, since a loose crystal packing of the tetrapodal molecules was anticipated, the X-ray analyses showed that the crystals obtained contained cocrystallized solvent molecules.

The analyses also indicated that in the clathrates, with composition 1c $\cdot 2 \mathrm{DMF} \cdot 2 \mathrm{H}_{2} \mathrm{O}$ and $2 \mathbf{b} \cdot 2 \mathrm{DMSO}$, respectively, the tetrapodal molecules held the solvent molecules using hydrogen-bonding (Figs. 3 and 4 ). In the case of $2 \mathbf{b} \cdot 2 \mathrm{DMSO}$ it is the $\mathrm{N}(1)$ that is connected to the oxygen of the solvent [N(1). .O(DMSO), 2.86 $\AA$ ]. In these crystals (Fig. 4) the tetrapodal molecules interact not only through hydrogen-bonding $\left[\mathrm{N}(2) . . \mathrm{O}\left(1^{\prime}\right), 2.94 \AA\right.$ ], but also in the way of a $\pi, \pi$ interaction through a cofacial pairing of the $p$-aminobenzamido rings $\mathrm{C}\left(8^{\prime}\right)-\mathrm{C}\left(13^{\prime}\right)$. An interesting feature of the crystals of $2 \mathbf{b} \cdot 2 \mathrm{DMSO}$ is that the enclathrated DMSO molecules are located in channels running parallel to the $b$ axis (Fig. 4). No attempts were made to obtain solvent-free crystals with empty pores, but a control X-ray analysis was carried out on crystals that had remained in air at ambient temperature for more than 2 years. The analysis showed that the crystal structure had not changed and that the enclathrated DMSO molecules were still present.

\section{Reticular Aramids}

Polycondensations of a tetrapodal monomer with a stiff bifunctional comonomer afford a convenient way for obtaining rigid networks with evenly spaced, tetrahedral branch points (Fig. 5). The networks can be highly porous materials with windows and cavities-all identical in the case of ideal 3D-ordered networks-of very large size. In the aramid networks obtained, as in

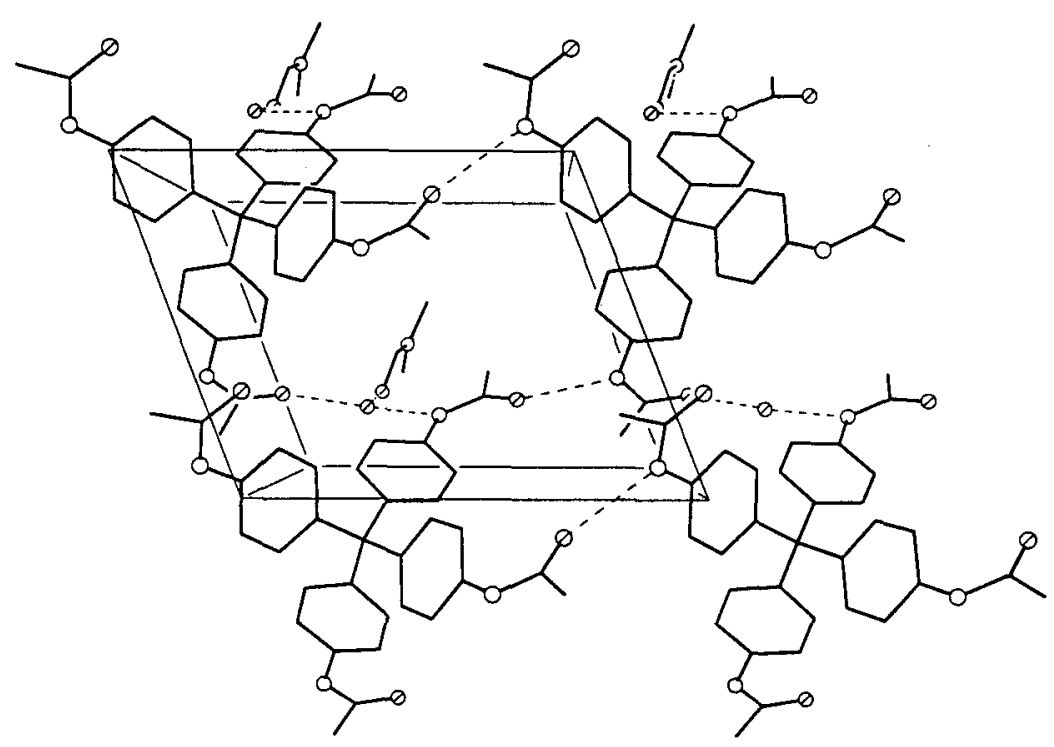

Fig. 3. A section through the crystal structure of $1 c \cdot 2 \mathrm{DMF} \cdot 2 \mathrm{H}_{2} \mathrm{O}$. Only half the depth of the unit-cell contents, in the direction of the $c$ axis, is shown. The hydrogen bonds are indicated by dashed lines; $\odot$, nitrogen; $\oslash$, oxygen. Note that there is no direct hydrogen bond between 1c and DMF. 


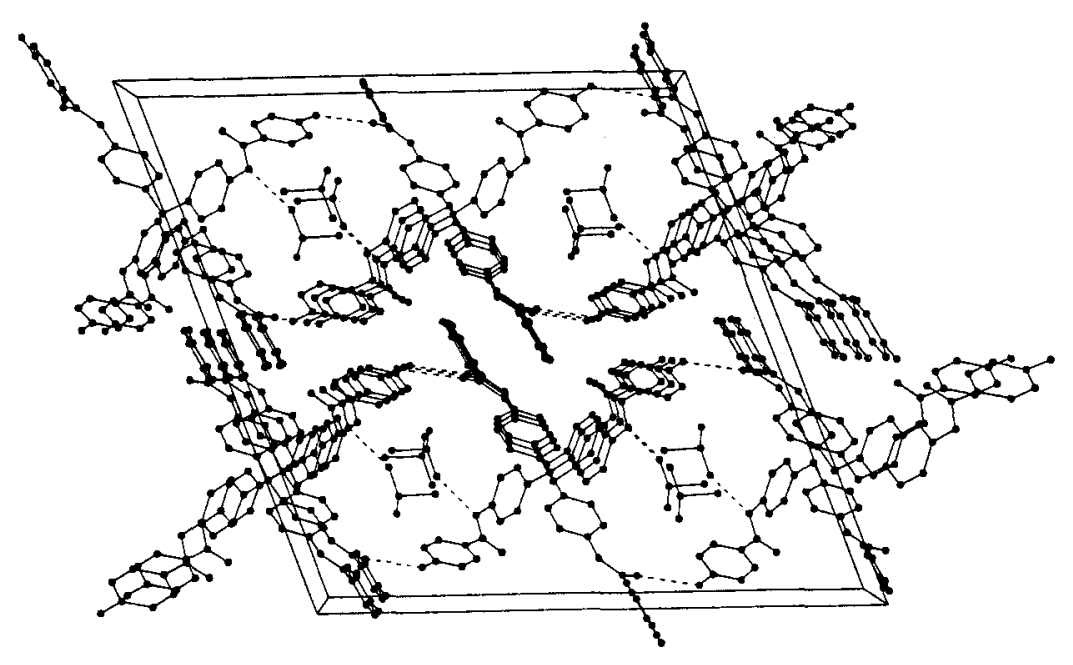

Fig. 4. Perspective view of $\mathbf{2 b} \cdot 2 \mathrm{DMSO}$ down the center of the unit cell in the direction of the $b$ axis. The view shows four channels with the DMSO molecules. The paired rings at the center of the cell are the rings $\mathrm{C}\left(8^{\prime}\right)-\mathrm{C}\left(13^{\prime}\right)$ (Fig. 2). The dashed lines are hydrogen bonds between $N(1)$ and $O(D M S O)$ and between $N(2)$ and $O\left(1^{\prime}\right)\left[N\left(2^{\prime}\right)\right.$ and $O(1)$, not regarded as hydrogen-bonded, come as close as $3.00 \AA$ to each other].

this work, from $1 \mathrm{~b}$ and terephthalic acid, having a distance of about $19 \AA$ between branch points, more than $80 \%$ of the volume could be free. Highly porous, rigid aramid networks, including even some with identical distances between branch points, have been prepared and also thoroughly investigated by Aharoni and co-workers [23-27]. These networks, however, differ from those synthesized in the present work in that they were obtained from nontetrapodal and generally less than tetrafunctional monomers and in that their branch points were only trifunctional.

Although they might be appropriate for the preparation of thin layers of $3 \mathrm{D}$-ordered reticular aramids, Schotten-Baumann conditions, which are normally used

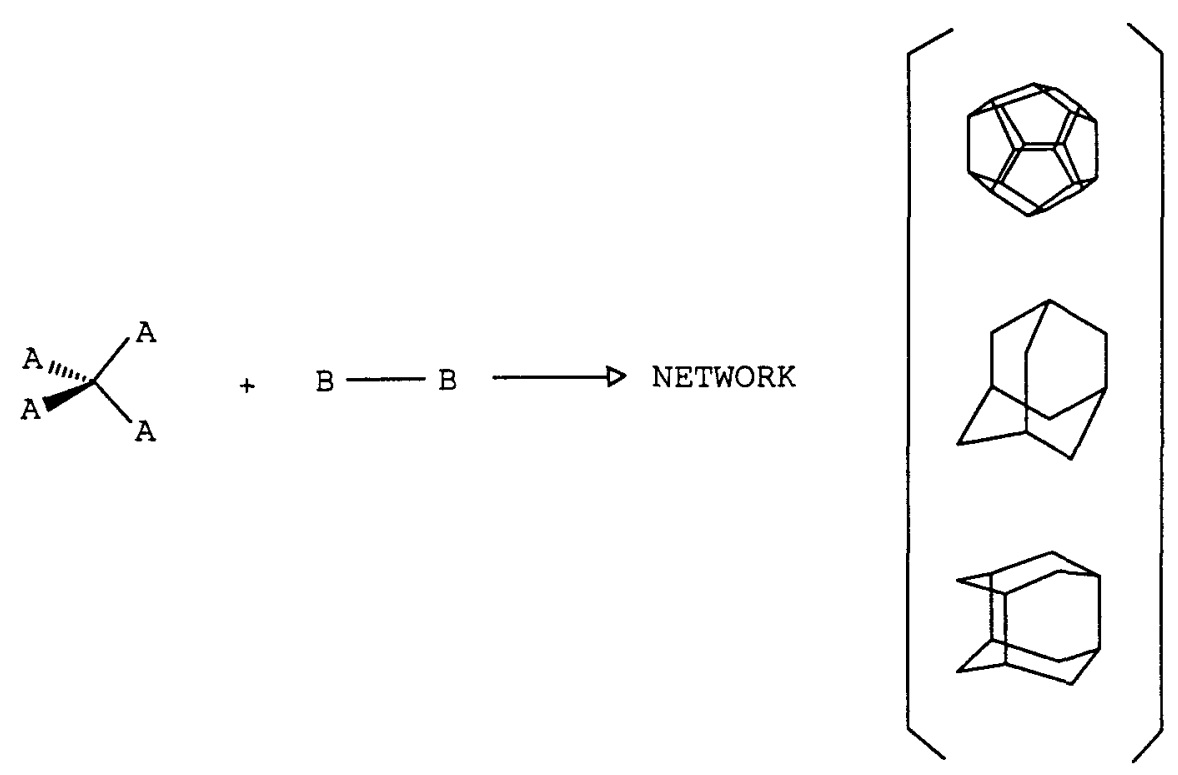

Fig. 5. Synthesis of a rigid covalent network by polycondensation, and possible types of elementary cages. A and B are functional groups. The cages have windows with frames containing five or six residues of the tetrapodal monomer. Frames with three or four residues are unlikely. 
[28] for the preparation of linear aramids, were impractical for the intended purpose. Therefore, the polycondensation experiments were carried out under Yamazaki conditions [29]. The two monomers (1b and terephthalic acid) and the activator (triphenyl phosphite) were combined in NMP/Py at -10 to $-20^{\circ} \mathrm{C}$ in order to ensure uniform mixing prior to the formation of insoluble reticular products; then the temperature was raised to $115^{\circ} \mathrm{C}$ and the reaction was allowed to proceed at this optimum temperature [30]. In all cases the volume of the reaction mixture was large enough for the monomers used to be able to polymerize, in principle, to an ideal network without interpenetration.

All polycondensations yielded transparent, flawless gels that, like Aharoni's most densely cross-linked samples [23], encompassed the whole volume of the reaction mixture. The gels did not change much in volume upon equilibration with solvents such as $\mathrm{MeOH}$ or EtOAc, but they developed cracks and shrunk markedly on evaporation of the solvent(s). No attempt was made to dry the gels under conditions avoiding collapse [31]. IR measurements $(\mathrm{KBr})$ on samples obtained by drying gels equilibrated in $\mathrm{MeOH}$ showed a very broad, strong amide $\mathrm{NH}$-stretch band at $3200-3400 \mathrm{~cm}^{-1}$ and various bands in the $\mathrm{C}=\mathrm{O}$-stretch (amide I) region. These features are consistent with a structure formed by the collapse of a porous polyamide network with the amide groups isolated and unable to interact with one another [24]. Neither the gels nor the collapsed dry networks showed crystallinity. This was not unexpected; lack of long-range 3D order can result from nonuniformity of the cavities, interlocking, dangling chains, and voids, and these structural imperfections can hardly be avoided in the synthetic approach used [7, 8, 27].

Even if not crystalline, these networks remain interesting. The evenly spaced tetrahedral branchpoints should confer at least some degree of uniformity in cavity size and this might be significant enough for useful applications. Further work, however, is needed to establish the validity of these expectations.

\section{EXPERIMENTAL}

\section{General}

Commercial reagents and solvents of the best available quality were used. NMP (1-methyl-2-pyrrolidone) was refluxed under vacuum in the presence of $\mathrm{CaH}_{2}$ and then distilled. Triphenyl phosphite was purified by fractional distillation under vacuum.

M.p.: Kofler melting point apparatus and Mettler DSC 30. IR spectra: Nicolet-5SCX Fourier-transform

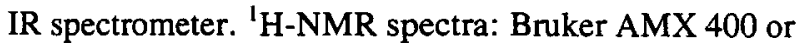
AMX 500 operating at 400.13 and $500.13 \mathrm{MHz}$, respectively; $\delta_{\mathrm{H}}$ (DMSO- $\mathrm{d}_{6}, 10-20 \mathrm{mg} / \mathrm{ml}$, unless otherwise indicated, $25^{\circ} \mathrm{C}$ ) in ppm relative to $\mathrm{Me}_{4} \mathrm{Si}$.

\section{Syntheses}

\section{Tetrakis (4-aminophenyl)methane (1b)}

This compound was prepared starting from triphenylmethyl chloride and aniline. The procedure described in the literature [18] was followed, but the catalytic reduction of tetrakis(4-nitrophenyl)methane (1a) was carried out using NMP rather than EtOAc as solvent. The other conditions were $80^{\circ} \mathrm{C}, \mathrm{H}_{2}$ at atmospheric pressure, and about $8 \mathrm{~h}$ reaction time. $1 \mathrm{~b}$ was recrystallized from $\mathrm{DMSO} / \mathrm{H}_{2} \mathrm{O}$, m.p. $331^{\circ} \mathrm{C}$ (lit. [18], $319-20^{\circ} \mathrm{C}$ ).

\section{Tetrakis(4-acetamidophenyl)methane (1c)}

Acetyl chloride $(2.0 \mathrm{ml}, 28 \mathrm{mmol})$ and $1 \mathrm{~b}(0.102$ $\mathrm{g}, 0.268 \mathrm{mmol}$ ) were mixed in $10 \mathrm{ml}$ of NMP. After 2 $\mathrm{h}$ the product was precipitated by an excess of water, and purified by recrystallization from DMF/nitrobenzene. No melting was observed up to the maximum temperature reached $\left(350^{\circ} \mathrm{C}\right) ; \delta_{\mathrm{H}}: 9.90(4 \mathrm{H}, \mathrm{s}, \mathrm{NH}), 7.46$ $(8 \mathrm{H}, \mathrm{d}$, aromatic $), 6.99(8 \mathrm{H}, \mathrm{d}$, aromatic), $2.01(12 \mathrm{H}$, $\mathrm{s}, \mathrm{CH}_{3}$ ).

\section{Tetrakis[4-(4-nitrobenzamido)phenyl]methane (2a)}

A mixture of $1 \mathrm{~b}(1.76 \mathrm{~g}, 4.63 \mathrm{mmol})$, 4-nitrobenzoyl chloride $(5.16 \mathrm{~g}, 27.80 \mathrm{mmol})$, Py $(3.5 \mathrm{ml}, 43$ $\mathrm{mmol})$, and NMP $(30 \mathrm{ml})$ was stirred for $6 \mathrm{~h}$ at reflux and for 2 days at $25^{\circ} \mathrm{C}$. The insoluble product obtained was suspended in $\mathrm{CHCl}_{3}$ and washed with aqueous $\mathrm{NaOH}\left(10^{-4} \mathrm{M}\right)$ and then with water. Final purification was by recrystallization from Py/MeOH. Yield, $2.58 \mathrm{~g}$ (57\%); m.p. $374^{\circ} \mathrm{C}($ dec. $) ; \delta_{\mathrm{H}}: 10.62(4 \mathrm{H}, \mathrm{s}, \mathrm{NH}), 8.37$ $(8 \mathrm{H}, \mathrm{d}$, aromatic), $8.17(8 \mathrm{H}, \mathrm{d}$, aromatic), $7.75(8 \mathrm{H}, \mathrm{d}$, aromatic), 7.19 (8H, d, aromatic).

Tetrakis[4-(4-aminobenzamido)phenyl]methane (2b)

2a $(0.63 \mathrm{~g}, 0.64 \mathrm{mmol})$ in DMSO $(150 \mathrm{ml})$ was reduced at $60^{\circ} \mathrm{C}$ with hydrazine monohydrate $(2.0 \mathrm{ml}$, $40 \mathrm{mmol} ; 1.0 \mathrm{ml}$ added additionally after $3 \mathrm{~h}$ ) in the presence of finely divided $\beta-\mathrm{FeO}(\mathrm{OH})$ as catalyst [32] $(1.1 \mathrm{~g} ; 0.2 \mathrm{~g}$ added additionally after $3 \mathrm{~h}$ ). After $6 \mathrm{~h}$, the catalyst was removed by filtration, and the product was precipitated and washed with water. Yield of dry, slightly yellow pink, product, $0.45 \mathrm{~g}(85 \%) ; \delta_{\mathrm{H}}: 10.16$ $(4 \mathrm{H}, \mathrm{s}, \mathrm{NH}), 7.69(16 \mathrm{H}, 2$ (overlapped) d, aromatic), $7.09(8 \mathrm{H}, \mathrm{d}$, aromatic $), 6.59(8 \mathrm{H}, \mathrm{d}$, aromatic ortho to $\left.\mathrm{NH}_{2}\right), 5.77\left(8 \mathrm{H}, \mathrm{s}, \mathrm{NH}_{2}\right)$. The crystals for the X-ray analysis were obtained by recrystallization from $\mathrm{DMSO} /$ $\mathrm{H}_{2} \mathrm{O}$. 


\section{Tetrakis \{[4-(4-acetamidobenzamido)phenyl]methane (2c)}

Analogously to $1 \mathrm{c}$, from acetyl chloride $(2.0 \mathrm{ml}$, $28 \mathrm{mmol})$ and $2 \mathrm{~b}(0.116 \mathrm{~g}, 0.135 \mathrm{mmol})$ in $10 \mathrm{ml}$ of NMP. Yield, $0.13 \mathrm{~g}(95 \%) ; \delta_{\mathrm{H}}: 10.18(4 \mathrm{H}, \mathrm{s}, \mathrm{NH})$, $10.12(4 \mathrm{H}, \mathrm{s}, \mathrm{NH}), 7.90(8 \mathrm{H}, \mathrm{d}$, aromatic $), 7.70(16 \mathrm{H}$, 2 (overlapped) d, aromatic), $7.13(8 \mathrm{H}, \mathrm{d}$, aromatic), $2.07\left(12 \mathrm{H}, \mathrm{s}, \mathrm{CH}_{3}\right)$.

\section{Tetrakis $\{$ 4-(4-benzamido)benzamido]phenyl\}methane} (3)

A mixture prepared from $0.134 \mathrm{~g}(0.15 \mathrm{mmol})$ of $2 \mathrm{~b}, 3 \mathrm{ml}(25.7 \mathrm{mmol})$ of benzoyl chloride, and $10 \mathrm{ml}$ of NMP was left standing at $25^{\circ} \mathrm{C}$ for 1 day. The product was precipitated by adding $\mathrm{MeOH}$ and was purified by repeated recrystallizations from $\mathrm{DMF} / \mathrm{MeOH}$ and from $\mathrm{DMF} / \mathrm{H}_{2} \mathrm{O}$. Yield, $0.17 \mathrm{~g}(90 \%)$; m.p. $340-$ $345^{\circ} \mathrm{C} ; \delta_{\mathrm{H}}: 10.50(4 \mathrm{H}, \mathrm{s}, \mathrm{NH}), 10.20(4 \mathrm{H}, \mathrm{s}, \mathrm{NH}), 7.98$ $(24 \mathrm{H}$, overlapping signals, aromatic), $7.75(8 \mathrm{H}, \mathrm{d}$, aromatic), $7.65-7.50(12 \mathrm{H}$, overlapping signals, aromati:), 7.17 (8H, d, aromatic).

Tetraki: $\{\{4$-[4-(4-nitrobenzamido)]benzamido\}phenyl\},nethane (3a)

A mixture of $2 \mathrm{~b}(0.602 \mathrm{~g}, 0.702 \mathrm{mmol})$ and 4nitrobenzoyl chloride $(1.05 \mathrm{~g}, 5.63 \mathrm{mmol})$ in NMP ( 25 $\mathrm{ml}$ ) was stirred under $\mathrm{N}_{2}$ at $100^{\circ} \mathrm{C}$ for $5 \mathrm{~h}$. The product was precipitated by adding water, washed with $\mathrm{MeOH}$, and recrystallized first from $\mathrm{DMSO} / \mathrm{MeOH}$ and then from DMF/EtOAc. Yield $0.67 \mathrm{~g}(66 \%) ; \delta_{\mathrm{H}}: 10.81(4 \mathrm{H}$, s, $\mathrm{NH}), 10.24(4 \mathrm{H}, \mathrm{s}, \mathrm{NH}), 8.40(8 \mathrm{H}, \mathrm{d}$, aromatic), $8.22(8 \mathrm{H}, \mathrm{d}$, aromatic), $8.00(8 \mathrm{H}, \mathrm{d}$, aromatic), 7.95 $(8 \mathrm{H}, \mathrm{d}$, aromatic), $7.75(8 \mathrm{H}, \mathrm{d}$, aromatic), $7.17(8 \mathrm{H}, \mathrm{d}$, aromatic).

Tetrakis $\{\{$ 4-[4-(4-aminobenzamido)]benzamido\}phenyl 3 methane (3b)

3a $(0.673 \mathrm{~g}, 0463 \mathrm{mmol})$ in DMSO $(25 \mathrm{ml})$ was reduced at $90-100^{\circ} \mathrm{C}$ with hydrazine monohydrate $(2.0$

Table I. X-Ray Structure Analyses

\begin{tabular}{|c|c|c|}
\hline & lc & $2 \mathbf{b}$ \\
\hline \multicolumn{3}{|l|}{ Crystal data } \\
\hline Formula & $\mathrm{C}_{33} \mathrm{H}_{32} \mathrm{~N}_{4} \mathrm{O}_{4} / 2 \mathrm{C}_{3} \mathrm{H}_{7} \mathrm{NO} / 2 \mathrm{H}_{2} \mathrm{O}$ & $\mathrm{C}_{53} \mathrm{H}_{44} \mathrm{~N}_{8} \mathrm{O}_{4} / 2 \mathrm{C}_{2} \mathrm{H}_{6} \mathrm{OS}$ \\
\hline Color, habit & Colorless prism & Yellowish platelet \\
\hline Crystal system & Triclinic & Monoclinic \\
\hline Space group & $P I$ & $I 2 / a$ \\
\hline$a(\AA)$ & $9.123(3)$ & $26.578(14)$ \\
\hline$b(\AA)$ & $11.401(5)$ & $7.868(6)$ \\
\hline$c(\dot{A})$ & $20.819(8)$ & $26.720(13)$ \\
\hline$\alpha\left(^{\circ}\right)$ & $89.76(3)$ & \\
\hline$\beta\left(^{\circ}\right)$ & $88.65(3)$ & $109.90(4)$ \\
\hline$\gamma\left({ }^{\circ}\right)$ & $68.71(3)$ & \\
\hline Volume $\left(\AA^{3}\right)$ & $2017.1(14)$ & $5254(5)$ \\
\hline$Z$ & 2 & 4 \\
\hline Formula weight & 730.9 & 1013.2 \\
\hline Density (calc.) $\left(\mathrm{g} \mathrm{cm}^{-3}\right)$ & 1.203 & 1.281 \\
\hline Absorption coefficient $\left(\mathrm{mm}^{-1}\right)$ & 0.085 & 1.394 \\
\hline$F(000)$ & 780 & 2136 \\
\hline Crystallization solvent & $\mathrm{DMF} /$ nitrobenzene & DMSO/water \\
\hline \multicolumn{3}{|l|}{ Data collection } \\
\hline Radiation & Mo $K \alpha$ & $\mathrm{Cu} K \alpha$ \\
\hline Temperature (K) & 293 & 293 \\
\hline $2 \theta$ Range (deg) & $3-40$ & $3-100$ \\
\hline Scan type & $\omega$ & $\omega$ \\
\hline Scan speed (deg/min) & $1.0-6.0$ & $1.00-4.00$ \\
\hline Scan range $(\omega)$ & 1.0 & 1.0 \\
\hline Independent reflections & 3770 & 2473 \\
\hline Observed reflections & 2398 & 1470 \\
\hline Absorption correction & None & None \\
\hline \multicolumn{3}{|l|}{ Solution and refinement } \\
\hline Solution & Direct methods & Direct methods \\
\hline Data-to-parameter ratio & $5.0: 1$ & $4.4: 1$ \\
\hline Final $R$ index (obs. data) & 0.056 & 0.040 \\
\hline
\end{tabular}


$\mathrm{ml}, 40 \mathrm{mmol}$ ) in the presence of $0.5 \mathrm{~g}$ of $\mathrm{Pd} / \mathrm{C}(10 \%)$ for $6 \mathrm{~h}$. The isolation and purification of the product was as for $\mathbf{2 b}$. Yield, $0.60 \mathrm{~g}(98 \%)$. The ${ }^{1}$ NMR spectra did not show substantial signals of unreacted, or incompletely reacted $3 \mathrm{a}$, but were otherwise complex. At 0.34 $\mathrm{mg} / \mathrm{ml}$ the following signals $\left(\delta_{\mathrm{H}}\right)$ were observed: for 8 NH's, at 10.18 (s) and 10.16 (s) (overlapping), and at 10.01 (s) (relative intensities, 1:0.35); for 48 aromatic H's, at 8.1-7.8 (overlapping signals), 7.74 (d), 7.17 (d), 6.90 (d), and 6.61 (d) (relative intensities, 1:0.65:0.4:0.1:0.2), for $4 \mathrm{NH}_{2}$ 's, at 8.84 (tentative; s), 8.60 (tentative; s), and 5.82 (s) (relative intensities, $1: 2: 5.1)$.

\section{Polycondensations}

The following experiment is representative. A solution of $0.241 \mathrm{~g}(0.635 \mathrm{mmol})$ of $1 \mathrm{~b}$ and $0.210 \mathrm{~g}(1.27$ mmol) of terephthalic acid in $1.40 \mathrm{ml}$ of NMP and 0.56 $\mathrm{ml}$ of Py was cooled to $-15^{\circ} \mathrm{C}$ and then $0.795 \mathrm{~g}(3.54$ mmol) of triphenylphosphite in $1.40 \mathrm{ml}$ of NMP was added. The volume of the mixture thus obtained was about $4.0 \mathrm{ml}$. Up to four times larger relative volumes of solvents were used in other experiments. The mixture was homogenized by shaking and then it was heated at $115-120^{\circ} \mathrm{C}$ for $4 \mathrm{~h}$. This treatment yielded a transparent, craze-free yellowish gel encompassing the whole volume of the reaction mixture. For purification, $\mathrm{MeOH}$ $\left(25 \mathrm{ml}\right.$ ) was added, and, after several hours at $60^{\circ} \mathrm{C}$, the liquid was discarded. This procedure was repeated until evaporation of the liquid at the rotary evaporator left only a negligible residue.

\section{X-Ray Crystal-Structure Analysis}

See Table I. Crystallographic data have been deposited at the Cambridge Crystallographic Data Center, University Chemical Laboratory, 12 Union Road, Cambridge CB2 1EZ, UK.

\section{ACKNOWLEDGMENTS}

We thank S. Alpern, who actively participated in this work in its initial phase, and J. D. Wissmann, who performed the first reduction of $2 \mathbf{a}$.

\section{REFERENCES}

1. Schartel, B.; Stümpflen, V.; Wendling, J.; Wendorff, J. H. Polym. Adv. Technol. 1996, 7, 160.

2. Braun, D.; Reubold, M.; Wegmann, M.; Wendorff, J. H. Makromol. Chem. Rapid Commun. 1991, 12, 151.

3. Reichert, V. R.; Mathias, L. J. Macromolecules 1994, 27, 7024.

4. Husband, D. M.; Dotrong, M.; Dean, D. R.; Wang, C. S.; Dotrong, M. H.; Click, W. E.; Evers, R. C. Polymer Preprints $1995,36(1), 221$.

5. Wilson, L. M.; Griffin, A. C. J. Mater. Chem. 1993, 3, 991.

6. Eaton, P. E.; Galoppini, E.; Gilardi, R. J. Am. Chem. Soc. 1994, $116,7588$.

7. Ermer, O. J. Am. Chem. Soc. 1988, 110, 3747.

8. Hoskins, B. F.; Robson, R. J. Am. Chem. Soc. 1990, 112, 1546.

9. Simard, M.; Su, D.; Wuest, J. D. J. Am. Chem. Soc. 1991, 113, 4696.

10. Ermer, O.; Lindenberg, L. Helv. Chim. Acta 1991, 74, 825.

11. Robson, R.; Abrahams, B. F.; Batten, S. R.; Gable, R. W.; Hoskins, B. F.; Liu, J. In Supramolecular Architecture-Synthetic Control in Thin Films and Solids; Bein, T., ed.; American Chemical Society, 1992, p. 256.

12. Wang, X.; Simard, M.; Wuest, D. J. Am. Chem. Soc. 1994, 116,12119 .

13. Zaworotko, M. J. Chem. Soc. Rev. 1994, 23, 283.

14. Webster, O. W.; Gentry, F. P.; Farlee, R. D.; Campbell, G. C.; Urban, C.; Smart, B. E. Polymer Preprints 1993, 34(2), 694.

15. Chapman, O. L.; Magner, J.; Ortiz, R. Polymer Preprints 1995, $36(1), 739$.

16. Lorenzi, G. P.; Tomasic, L.; Suter, U. W. Macromolecules 1993, 26, 1183.

17. Lorenzi, G. P.; Manessis, A.; Suter, U. W.; Gramlich, V. Presented at the 3rd International Symposium on Polymers for Advanced Technologies, 11-15 June 1995, Pisa, Italy.

18. Neugebauer, F. A.; Fischer, H.; Bernhardt, R. Chem. Ber. 1976, $109,2389$.

19. Furst, A.; Berlo, R. C.; Hooton, S. Chem. Rev. 1965, 65, 51.

20. Backson, S. C. E.; Bayliff, P. M.; Feast, W. J.; Kenwright, A. M.; Parker, D.; Richards, R. W. Makromol. Symp. 1994, 77, 1.

21. Robbins, A.; Jeffrey, G. A.; Chesick, J. P.; Donohue, I.; Cotton, F. A.; Frenz, B. A.; Murillo, C. A. Acta Cryst. 1975, B31, 2395.

22. Johnson, C. K. ORTEP; Report ORNL-3794; Oak Ridge National Laboratory, Tennessee.

23. Aharoni, S. M.; Edwards, S. F. Macromolecules 1989, 22, 3361.

24. Aharoni, S. M.; Hatfield, G. R.; O'Brien, K. P. Macromolecules 1990, 23, 1330.

25. Aharoni, S. M.; Murthi, N. S.; Zero, K.; Edwards, S. F. Macromolecules 1990, 23, 2533.

26. Aharoni, S. M. Macromolecules 1992, 25, 1510.

27. Aharoni, S. M.; Edwards, S. F. Rigid Polymer Networks; Berlin: Springer-Verlag, 1994.

28. Kwolek, S. L.; Memeger, W.; Van Trump, J. E. In Polymers for Advanced Technologies; Lewin, M., ed.; VCH Publishers, 1988 , p. 421.

29. Yamazaki, N.; Matsumoto, M.; Higashi, F.; J. Polym. Sci. Polym. Chem. Ed. 1975, 13, 1373.

30. Krigbaum, W. R.; Kotek, R.; Mihara, Y.; Preston, J. J. Polym. Polym. Chem. Ed. 1985, 23, 1907.

31. Brinker, C. J.; Scherer, G. W. Sol-Gel Science, The Physics and Chemistry of Sol-Gel Processing; Academic Press 1990.

32. Miyata, T.; Ishino, Y.; Hirashima, T. Synthesis 1978, 834. 